\title{
BORON ABUNDANCE AND LOCALIZATION IN GRANULITES AND THE LOWER CONTINENTAL CRUST*
}

\author{
MARILYN G. TRUSCOTT; D. M. SHAW and J. J. CRAMER ${ }^{+}$
}

TRUSCOTT, MARILYN G.; SHAW, D. M. and CRAMER, J. J., 1986: Boron abundance and localization in granulites and the lower continental crust. Bull. Geol. Soc. Finland 58, Part 1, 169-177.

Fifty-five Precambrian ultramafic to felsic granulites from Pikwitonei, Westport, Adirondack Mountains, Orissa, Madras, and Minnesota and granulite xenoliths from Montana have been analyzed by Prompt Gamma Neutron Activation Analysis and alpha-track mapping.

Boron contents vary between $<0.1$ and 14 ppm, except for 3 rocks containing $>100 \mathrm{ppm}$, and do not show any relationship to other major or trace elements. The $\mathrm{B}$ abundance is proportional to the abundance of hydrous alteration products (sericite, saussurite, chlorite) which contain up to $500 \mathrm{ppm}$, in a given rock. Boron also is concentrated in some cases in mineral cleavages, along grain boundaries and along rock fractures: in some samples it is localised at points within plagioclase grains which might represent fluid inclusions.

The rock-forming minerals also contain a little homogeneously distributed $\mathrm{B}$, with abundance decreasing from: biotite > clinopyroxene > orthopyroxene, amphibole, plagioclase $>$ perthite, quartz.

The average abundance of $\mathrm{B}$ in the lower continental crust may be approximated by the average granulite. With a weighting of $54: 13: 31: 2$ for silicic : intermediate : basic : anorthosite + sedimentary gneiss, the lower crust averages $9.3 \mathrm{ppm}$, close to our $9.2 \mathrm{ppm}$ average for the upper crust. If samples which show a anomalously high alteration of plagioclase are eliminated, the lower crust averages only $2.8 \mathrm{ppm}$ : this latter figure is more representative of fresh lower crustal material.

Key words: boron, granulites, metamorphism, alteration, geochemistry.

Marilyn G. Truscott; D. M. Shaw and J. J. Cramer: Department of Geology, McMaster University, Hamilton, Ontario, L8S 4M1, Canada.

+ Present address: Atomic Energy of Canada, Pinewa, Manitoba, Canada.

\section{Introduction}

The average abundance of boron in the lower crust and the role of this region in the lithospheric cycle of boron have not yet been established. Harder (1974) declined to give an average B con-

\footnotetext{
* Contribution 143 of the McMaster Isotopic, Nuclear and Geochemical Studies Group.
}

tent for high-grade metamorphic rocks since too few analyses were available.

Our studies of $\mathrm{B}$ in a varied selection of granulites therefore focus on understanding the factors which control B abundance, including initial B content, mineralogy, and metamorphic and tectonic history of the host rock, with a view toward establishing a reasonable estimate for $\mathrm{B}$ abundance in the lower continental crust. 


\section{Analytical methods}

Samples were analyzed for B using two methods, Prompt Gamma Neutron Activation Analysis (PGNAA) and alpha-track mapping. Bulk $\mathrm{B}$ in rock powders was determined by counting the $478 \mathrm{keV}$ prompt gamma peak emitted by 1 to $2 \mathrm{~g}$ of powder irradiated in a thermalized neutron beam (flux $6 \times 10^{7} \mathrm{n} . \mathrm{cm}^{-2} \mathrm{sec}^{-1}$ ) for 1000 to 4000 seconds in the PGNAA facility at the McMaster Nuclear Reactor (Higgins et al. 1984), using a $12 \%$ efficiency Ge-Li detector specially manufactured to exclude B-bearing components. Precision of the method is better than $2 \%$ (Truscott and Shaw 1984) and sensitivity is $0.1 \mathrm{ppm}$ with a $2 \mathrm{~g}$ sample. Boron, ana- lyzed as ${ }^{10} \mathrm{~B}$, is calculated to total $\mathrm{B}$ assuming no isotopic enrichment.

The spatial distribution of B was studied with alpha-track methods (e.g. Fleischer et al. 1975) by irradiating sensitive cellulose nitrate $(\mathrm{CN}-85)$ detectors in contact with polished thin sections to a total fluence of $\sim 10^{13} \mathrm{n} . \mathrm{cm}^{-2}$ (adjacent to the reactor core). After cooling to reduce harmful induced decay products, the detectors were removed and etched with $2.5 \mathrm{~N} \mathrm{NaOH}$ solution at $50^{\circ} \mathrm{C}$ for 20 minutes to reveal the areas damaged by alpha-particles from the reaction: ${ }^{10} \mathrm{~B}+\mathrm{n} \rightarrow$ ${ }^{7} \mathrm{Li}+\underline{\alpha}$. Comparison of thin sections and the corresponding $\alpha$-track maps indicates where B was localised in the rocks. Rock lithium can contribute to the alpha-track map, and was monitored

Table 1. PGNA analyses of bulk rocks.

\begin{tabular}{|c|c|c|c|c|}
\hline Symbol ${ }^{+}$ & Sample location & Boron content ppm & $\begin{array}{l}\text { No. of } \\
\text { analyses }\end{array}$ & $\begin{array}{l}\text { Boron } \\
\text { average ppm }\end{array}$ \\
\hline $\mathrm{a}$ & $\begin{array}{l}\text { Adirondack }^{1} \\
\text { Mountains, USA }\end{array}$ & $\begin{array}{l}126,105,11.2,9.4,6.5 \\
5.5,4.5,4.4,3.4,2.9 \\
2.9,1.4\end{array}$ & 12 & $24(5.2)^{*}$ \\
\hline $\mathrm{p}$ & $\begin{array}{l}\text { Pikwitonei, }{ }^{2} \\
\text { Manitoba, Canada }\end{array}$ & $\begin{array}{l}13.7,11.1,11.0,9.5 \\
4.9,4.5,4.2,3.5,3.0 \\
2.9,2.7,2.5,2.4,2.0 \\
2.0,1.9,1.7,1.7,1.6 \\
1.4,1.2,0.8,0.7, \\
0.6,0.6,0.5,0.3\end{array}$ & 27 & 3.4 \\
\hline w & $\begin{array}{l}\text { Westport, }{ }^{1} \\
\text { Ontario, Canada }\end{array}$ & 255 & 1 & 255 \\
\hline $\mathrm{z}$ & $\begin{array}{l}\text { Minnesota River } 5 \\
\text { Valley, USA }\end{array}$ & $1.4,0.3$ & 2 & 0.9 \\
\hline $\mathrm{m}$ & Madras, India ${ }^{3}$ & $1.8,1.7,1.2,0.1,0.02$ & 5 & 1.0 \\
\hline o & Orissa, India ${ }^{3}$ & $6.7,2.3,1.1,0.5$ & 4 & 2.7 \\
\hline \multirow[t]{2}{*}{$\mathrm{x}$} & $\begin{array}{l}\text { Xenoliths, }{ }^{4} \\
\text { Missouri River } \\
\text { Breaks Diatremes } \\
\text { Montana, USA }\end{array}$ & $2.5,2.4,1.7,0.6$ & 4 & 1.8 \\
\hline & & All areas & 55 & 11.9 \\
\hline
\end{tabular}

Samples were contributed by:

1 J. J. Cramer, Atomic Energy of Canada, Pinawa, Manitoba, Canada

2 Jaap Hubregtse, Manitoba Department of Mines, Manitoba, Canada

3 Sisir Sen, Indian Institute of Technology, Kharagpur, India

4 B. Carter Hearn Jr., U. S. Geological Survey, Reston, Virginia, USA

5 D. M. Shaw

+ These symbols are used in Fig. 1, 2 .

* The value in parentheses is obtained by excluding the two high values. 
by mapping triton-tracks from Li using the reaction ${ }^{7} \mathrm{Li}+\mathrm{n} \rightarrow{ }^{3} \underline{\mathrm{H}}+\alpha$, with irradiation and etching as above but using a $25 \mu \mathrm{m}$ layer of aluminized mylar between the thin section and $\mathrm{CN}-85$ detector, to absorb $\alpha$-particles produced by both $\mathrm{Li}$ and $\mathrm{B}(\mathrm{n}, \alpha)$ reactions: this is a modification of techniques described by Stinson et al. (1975) and Carpenter and Pilione (1981). The triton-track maps showed that Li interference can be disregarded, in these samples.

\section{Bulk rock analysis results}

The samples used consist of a suite of granulite facies rocks assembled by J. J. Cramer. Another paper (Shaw et al., in press) discusses major and trace elements except for the REE, which will be

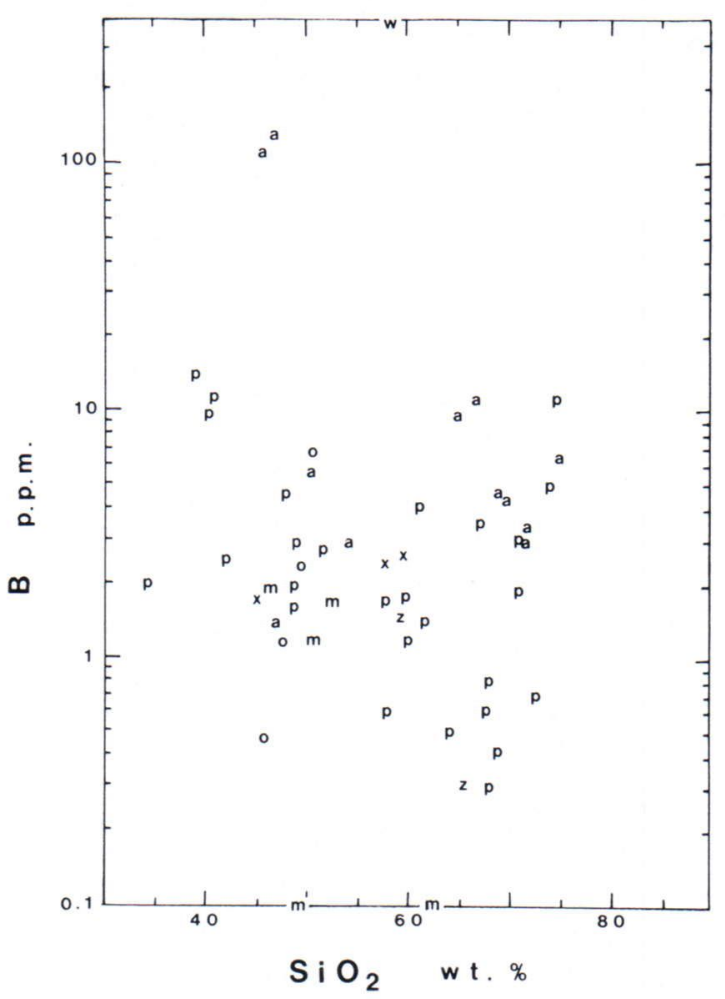

Fig. 1. $\mathrm{SiO}_{2}$ vs. B plot for the rocks reported in Table 1: the $\mathrm{SiO}_{2}$ values are not reported here. discussed in a paper under preparation by J. J. Cramer.

Boron analyses by PGNAA are listed in Table 1 . The bulk $\mathrm{B}$ content varies from 0.1 to $255 \mathrm{ppm}$, with most samples between 1 and $10 \mathrm{ppm}$. The Adirondack Mountains samples generally have the highest B contents, from 1.4 to $126 \mathrm{ppm}$ (average $23 \mathrm{ppm}$ ). The Pikwitonei samples contain 0.3 to $14 \mathrm{ppm}$ (average $3.4 \mathrm{ppm}$ ). The other samples are mostly below $2 \mathrm{ppm}$, except for the single Westport sample which has $255 \mathrm{ppm}$.

Since the rocks in each area vary considerably in composition and origin, it is not clear that averaging each data set is legitimate, because compositional differences or mineralogy might control in some way the B concentrations. To examine this possibility B was plotted against

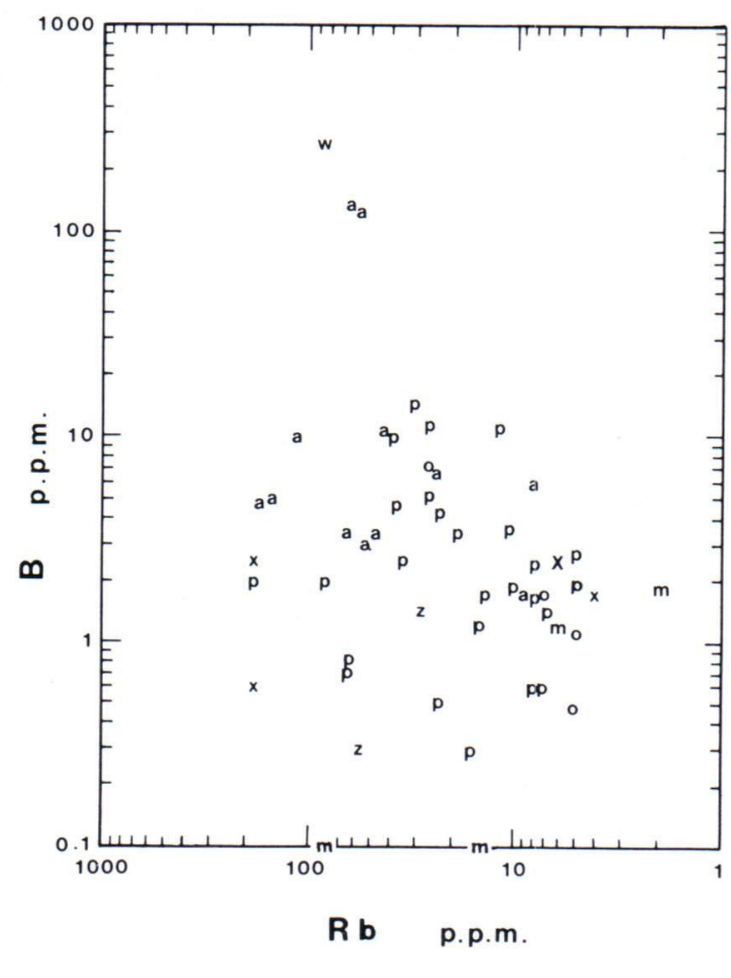

Fig. 2. Rb vs. B plot for the rocks reported in Table 1: the $\mathrm{Rb}$ values are not reported here. 

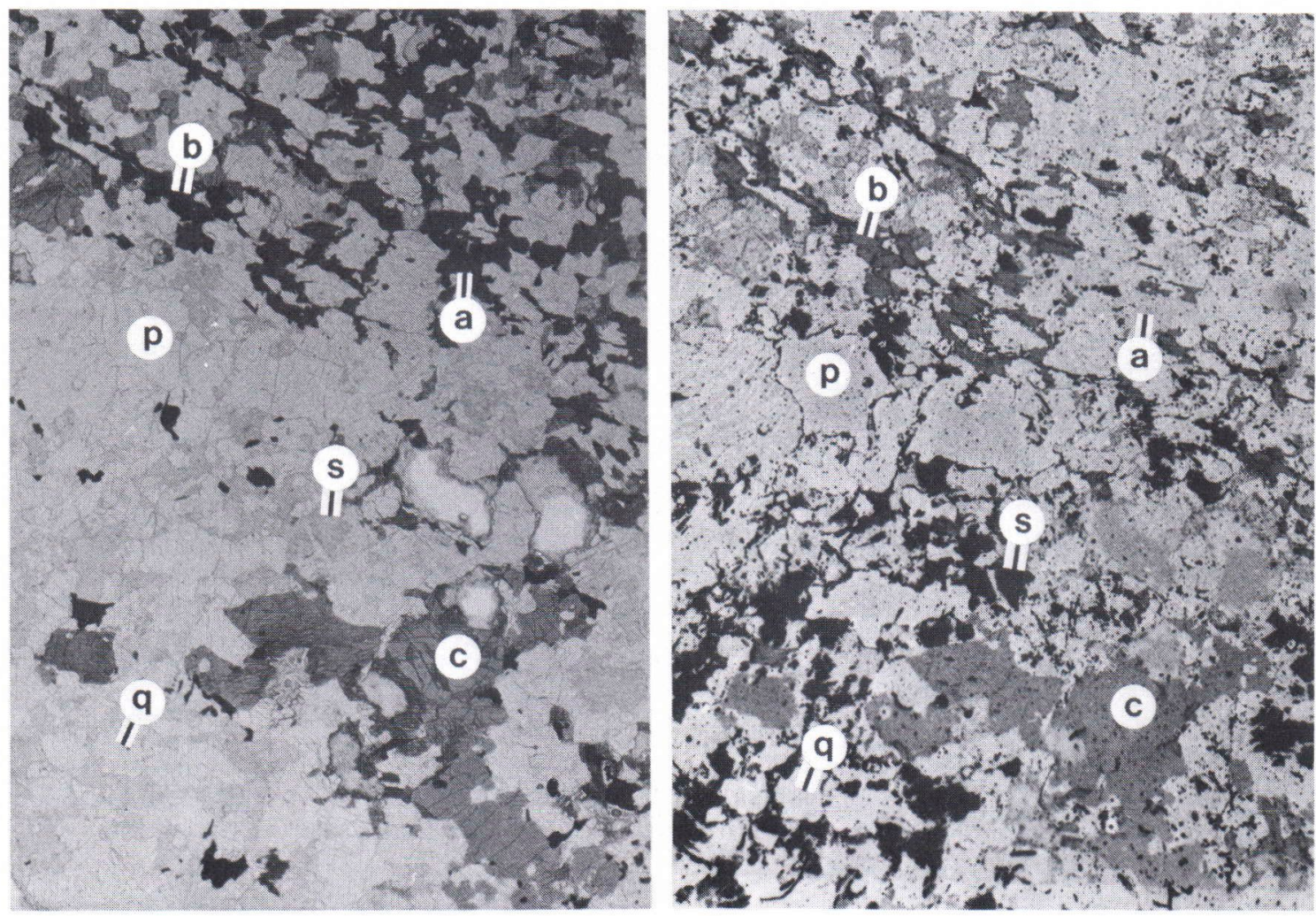

Fig. 3. Intermediate granulite 8006, Adirondacks; bulk B content $2.9 \mathrm{ppm}$; field of view $14 \times 21 \mathrm{~mm}$. Left: Thin-section, containing plagioclase (p), quartz (q), clinopyroxene (c), amphibole (a), with lesser amounts of biotite (b), garnet, Fe oxides: much of the plagioclase has been altered to a fine aggregate of sericite (s) which shows as slightly darker grey than fresh plagioclase and quartz. Right: Alpha-track map: the highest B concentration (darkest areas) is in sericite, followed by biotite, then clinopyroxene, with little in amphibole, garnet, unaltered plagioclase, quartz.

several elements, determined by X-ray fluorescence analysis.

In Figures 1 and 2, $\mathrm{B}$ is plotted against $\mathrm{SiO}_{2}$ and $\mathrm{Rb}$, respectively. These diagrams illustrate the lack of any clear relationship shown by B to other elements. The greater bulk of the B analyses fall in the range 0.2 to $10 \mathrm{ppm}$ and show little tendency for any distinctive relationship with region (as noted above) or with $\mathrm{SiO}_{2}$ or $\mathrm{Rb}$ abundance. However three samples differ markedly from the rest, in having $>100 \mathrm{ppm}$ B.

It is unusual to encounter an element whose distribution in rocks appears to bear no relation to overall rock composition, as in the present case. Such behaviour is however found with elements such as $\mathrm{Cu}$, $\mathrm{Au}$, whose localization is related often to factors external to a given rock type, such as fluid transport and deposition. It will be seen in the next section that such phenomena play a role in the case of $\mathrm{B}$, and evidence already is to be found in the literature.

Thus, Harder (1961) found that in granites B tends to be localised in plagioclase permeated with fine-grained mica. Waskowiak (1969) also found muscovite and sericitized plagioclase to be the most important B-bearing minerals. Malinko et al. (1979), used alpha-track methods to show the affinity of various rock-forming and alteration minerals for B. Ahmad and Wilson (1981), using qualitative nuclear track methods in the study of $U$ and $B$ in a suite of pelitic gneisses, determined that $\mathrm{B}$ tended to be concentrated in 

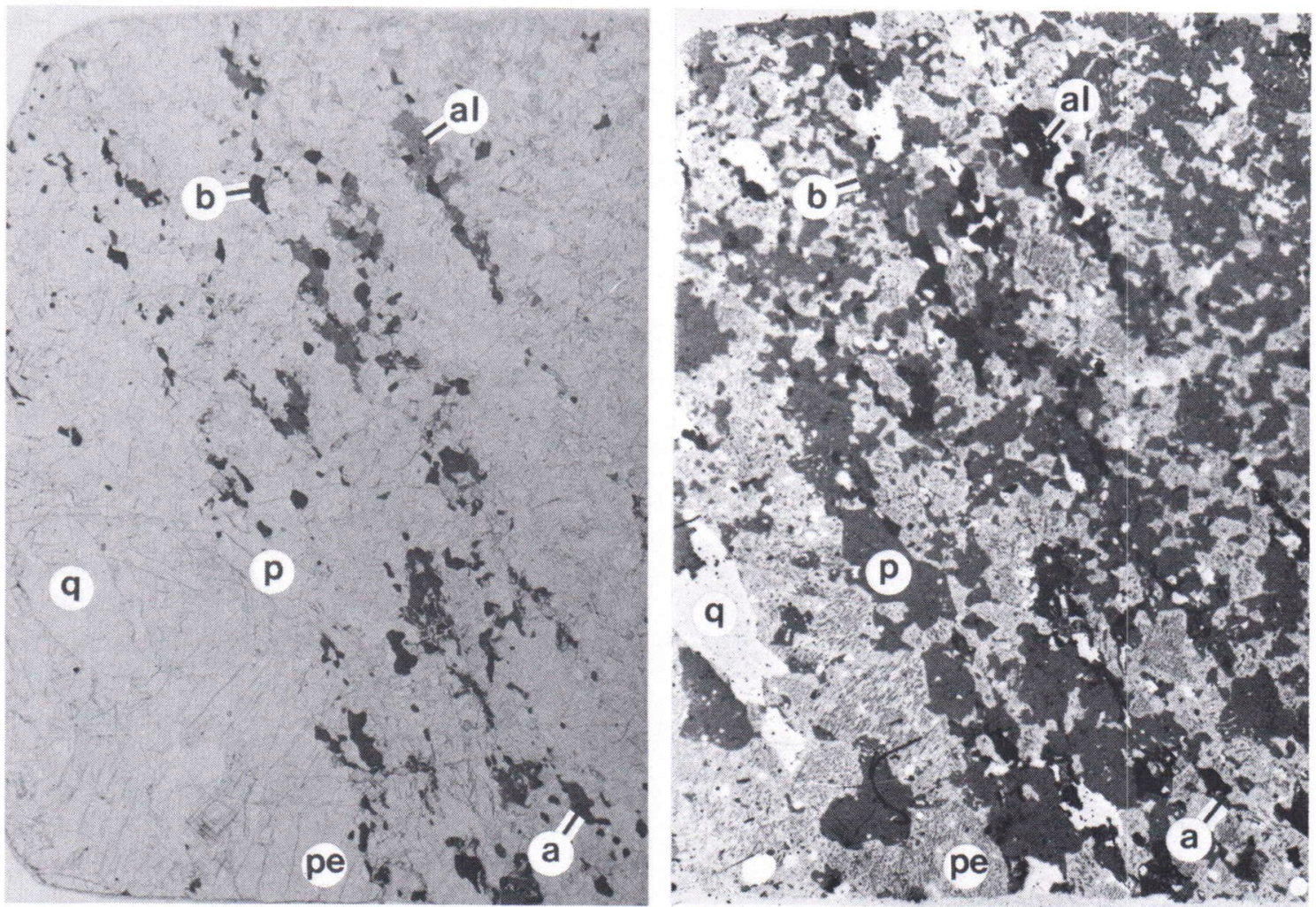

Fig. 4. Felsic granulite 8008, Adirondacks; bulk B content 9.4 ppm. Left: Thin-section: contains plagioclase (p), perthite (pe) and quartz (q), with minor phyllosilicate alteration (al), amphibole (a), biotite (b), Fe oxides. Right: Alpha-track map: the alteration has the highest B content, followed by biotite, plagioclase and amphibole, with least in perthite and quartz.

the sericitized and chloritized margins of perthite and biotite respectively, and in pinnite and sillimanite, and also along grain boundaries and fractures in quartz, perthite and garnet, suggesting that a fluid phase was related to mobilization of boron.

\section{Alpha-track analysis}

Alpha-track maps of our granulites are shown in Figs. 3 to 6, and indicate that B is concentrated according to five main styles, of decreasing importance as listed below.

1. Sericitic alteration within plagioclase (Fig. 3).

The concentration of $\mathrm{B}$ in sericite is estimated by comparisons of modal and bulk analyses to be up to $500 \mathrm{ppm}$. The sericite alteration affects plagioclase, rarely mafic minerals, and is developed inwards from cleavages and boundaries.

2. Sericite, saussurite and chlorite within foliation planes (Figs. 4, 5). These minerals are again alteration products, of plagioclase, biotite and other minor mafic minerals.

3. Along microscopic fractures (Figs. 5, 6). The B occurs in alteration minerals, along grain boundaries and in cracks in pyroxene, garnet and plagioclase associated with these fractures, as reported by Ahmad and Wilson (1981).

4. In small spots in plagioclase, which were not 

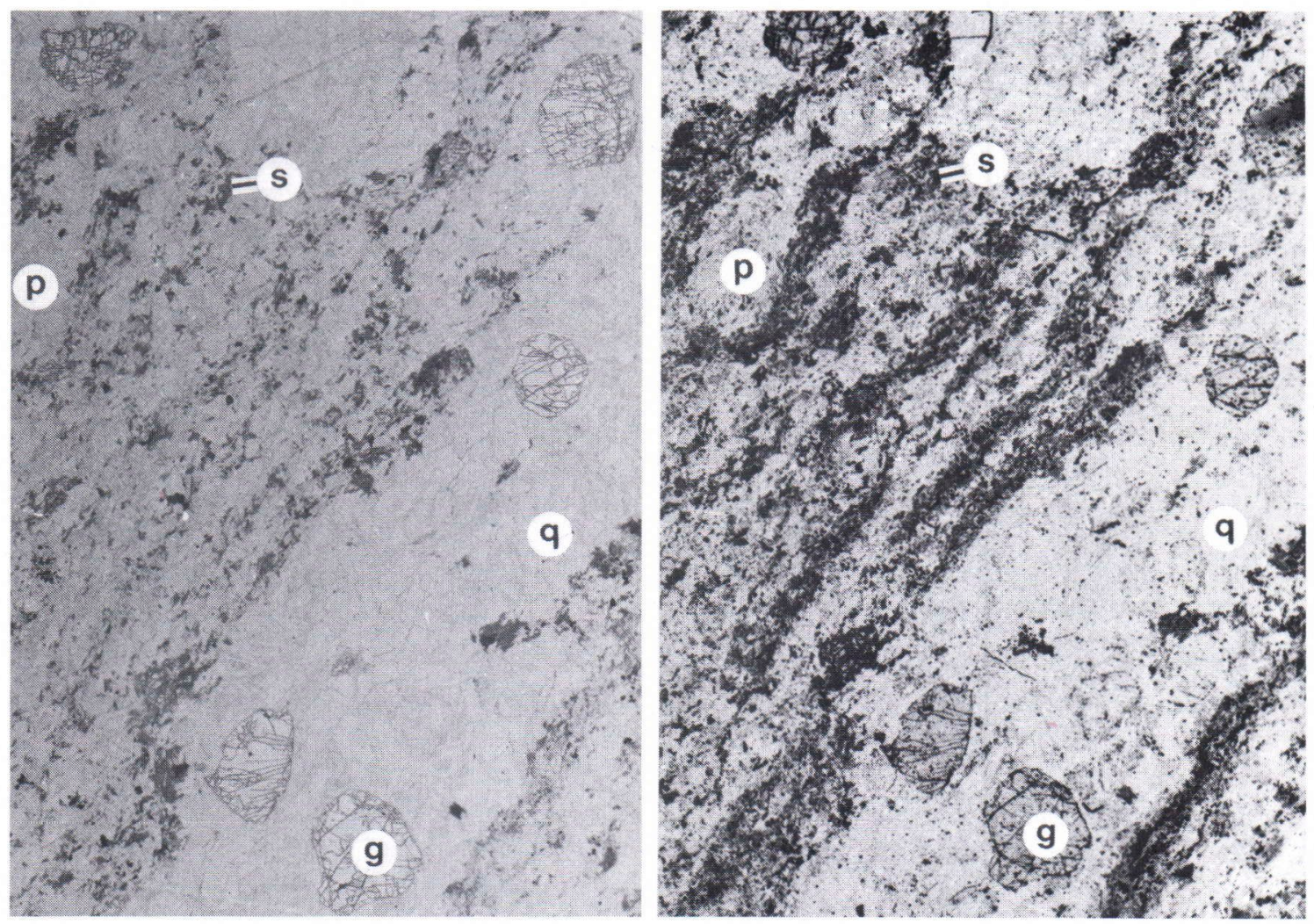

Fig. 5. Garnet granulite 8004, Adirondacks; bulk B content 4.5 ppm. Left: Thin-section: light minerals are quartz (q), untwinned plagioclase (p), orthoclase, all showing cataclasis. In addition to garnet ( $\mathrm{g})$, the foliation is defined by biotite, minor sericite (s), saussurite and chlorite. Right: Alpha-track map: Sericite and saussurite contain the most B, followed closely by chlorite and biotite, then garnet, with virtually nothing in the light minerals. Note the concentration of B in garnet fractures.

sericite or other distinct mineral grains, but could be fluid inclusions.

5. In the rock-forming minerals. The B content of most minerals is lower than in alteration minerals; with B decreasing as follows: biotite $>$ clinopyroxene $>$ orthopyroxene, plagioclase, amphibole, garnet $>$ perthite, quartz. This order agrees with some of the analyses presented by Harder (1974) and Malinko et al. (1979).

It was mentioned previously that three of the analyses reported in Table 1 are unusually high. Alpha-track maps were prepared of two of these, the Adirondacks samples, containing 126 and 105 ppm B respectively. In each case it was found that the plagioclase was largely altered to sericite and that the sericite was rich in B.

It should also be noted that none of the rocks studied here contained borosilicates, at least as discrete grains which could be recognized on $\alpha$-track films. The low B abundance in most of the samples precludes the presence of borosilicates. Although sapphirine was reported as a minor accessory mineral in some Pikwitonei rocks (J. J. Cramer, unpublished data), the extremely low B in the Pikwitonei samples (average $3.4 \mathrm{ppm}$ ) suggests that B-bearing kornerupine does not accompany it, or else that the stability limit of kornerupine has been exceeded.

The lack of correspondence between B and other mobile elements can thus be explained by 

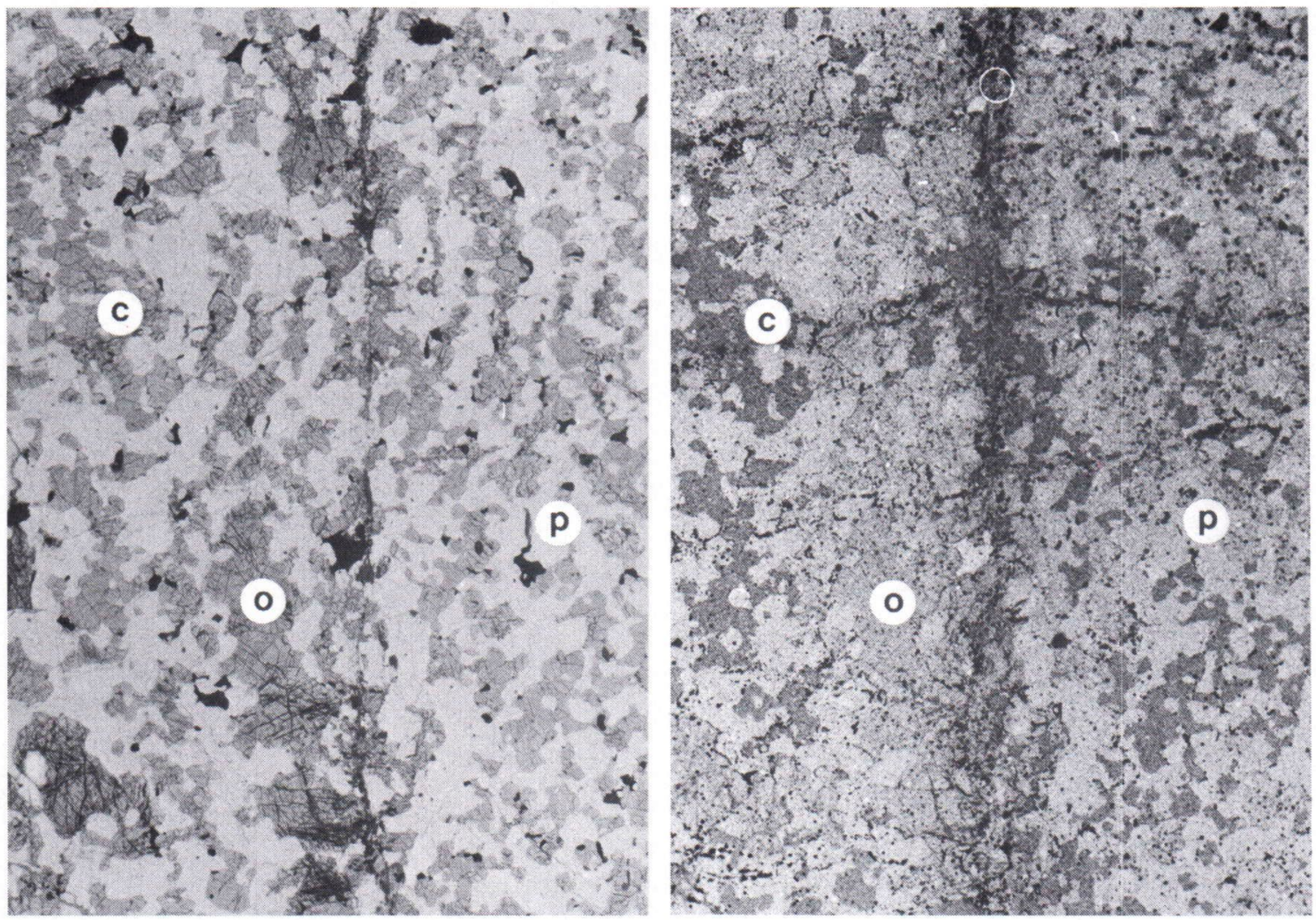

Fig. 6. Mafic granulite 8010, Adirondacks; bulk B content 5.5 ppm. Left: Thin-section: main minerals are clinopyroxene (c), orthopyroxene (o), plagioclase (p), and there are minor amounts of Fe oxides, biotite, amphibole and chlorite. Right: Alphatrack map: a marked concentration of B along fractures (in chlorite) stands out strongly. After chlorite, B is most abundant in biotite, then clinopyroxene, with little difference to be found between orthopyroxene, amphibole, plagioclase and quartz. The fractures indicate that some of the B was introduced from outside the rock.

the fact that most of the B occurs in late alteration minerals, and the control by rock-forming minerals is of lesser importance. This suggests that B uptake is related to late circulating fluids.

\section{Boron abundance in the lower continental crust (LCC)}

There is agreement among many geologists that granulite facies rocks are characteristic of the LCC, and consequently it can be argued that element abundances in such rocks can be used to model the composition of the LCC.

In the present case, however, the erratic distribution of B in the granulites examined, leading to the conclusion that the B abundance is a consequence of later fluid effects, raises the question as to whether an average abundance will have any real meaning.

Another difficulty is the question of what abundance proportions of different granulites (e.g. mafic vs. felsic) are appropriate to the LCC as a whole. This problem was examined by Shaw et al. (in press) who classified the same rocks on $\mathrm{SiO}_{2}$ per cent into four groups ( $>65: 65-55$ : $55-45 ;<45)$ and then weighted the average element abundances in each group in the proportions $54: 13: 31: 2$, disregarding any possible regional differences. These proportions were recognised however as not being very securely based. 
The result of such a calculation for B yielded a weighted mean of $9.3 \mathrm{ppm}$. This is not markedly different from the simple overall mean of 11.9 ppm in Table 1, as might be expected from the lack of any correlation with $\mathrm{SiO}_{2}$ in Fig. 1. If however the 3 values exceeding $100 \mathrm{ppm}$ are discarded, the weighted mean falls to $2.8 \mathrm{ppm}$ and the mean in Table 1 falls to $3.3 \mathrm{ppm}$. In the light of the fact that alteration appears to control the $B$ abundance it may be argued that the value of $2.8 \mathrm{ppm}$ is the most appropriate to take as the LCC estimate, since alteration may well have taken place subsequent to the time when these rocks formed part of the lower crust. The value of $9.3 \mathrm{ppm}$ was reported in Shaw et al. (in press), but $2.8 \mathrm{ppm}$ is more appropriate for fresh lower crustal material.

It may next be asked what significance is to be attached to the few ppm B which appear to be intrinsic to these granulites, i.e. not consequent on later alteration. The evidence from Figs. 3 to 6 indicates that this B is evenly distributed in the rock-forming minerals and thus presumably is present in structural sites. It is also evident that it preferentially entered biotite and clinopyroxene, where present, with lower abundances in the other minerals. Although the protoliths of many of the rocks analysed are uncertain, some are probably of sedimentary parentage, that is they are rocks which at a low metamorphic grade are commonly enriched in B.

It is tempting to ascribe the low B abundances to the conditions of granulite metamorphism, which are accompanied by evolution of volatile components: the B would largely be liberated, leaving only small amounts partitioned among the available host minerals.

Manning and Pichavant (1983) have shown that B-bearing rocks in the haplogranite system may begin to melt at lower temperatures than B-free rocks and that B enrichment by fluidrock interaction may allow melting to take place at lower temperatures, the resultant aqueous phase being enriched in $\mathrm{Si}, \mathrm{Al}, \mathrm{K}$, and $\mathrm{Na}$. However the $\mathrm{B}$ which is tied up in refractory borosili- cates, such as tourmaline, could be largely inaccessible until very high temperatures are achieved. For example, dravite only begins to break down at $895^{\circ} \mathrm{C}$ and $5 \mathrm{~kb}$ (as documented by Manning and Pichavant) to a B-bearing fluid, leaving kornerupine and sapphirine.

The rocks discussed here do not carry borosilicates, but it is not known whether this is because they never did, or because the borosilicates have in fact been destroyed. Certainly tourmaline is common in many sedimentary and low-grade metamorphic terranes, as an accessory or a vein mineral or both, so the absence is noteworthy.

Finally, if we are correct in assigning some of the point sources of B in granulite facies rocks to fluid inclusions within the rock-forming minerals, then this would be evidence for the presence of B-bearing fluids at the time of metamorphism. But this can not yet be substantiated.

\section{Summary}

In the 55 granulites studied, B abundances are mostly $<14 \mathrm{ppm}$. Three samples contain $>100 \mathrm{ppm}$. The concentration depends mainly on the abundance of hydrous alteration products, including sericite (up to $500 \mathrm{ppm}$ ), saussurite and chlorite. It also is concentrated in some rocks along fractures and along grain boundaries, cleavages and cracks, with no evidence that it has been leached from the surrounding rock. In these cases the B is present as a consequence of postmetamorphic fluid alteration.

A small proportion of the B in these rocks occurs within the rock-forming minerals, presumably substituted at structural sites. The B preferentially enters biotite, then clinopyroxene, then orthopyroxene, amphibole, plagioclase, then lastly perthite and quartz.

No tourmaline or other borosilicates were found in any of these rocks. Although some of the Pikwitonei samples contain sapphirine, which is commonly accompanied by kornerupine, etc., the Pikwitonei samples are low in B content and 
therefore were initially lacking in borosilicates or were raised above the stable $\mathrm{P}-\mathrm{T}$ conditions of kornerupine.

Since B appears to be related almost exclusively to late- or post-metamorphic fluids, no conclusions can be drawn about the prealteration $\mathrm{B}$ contents. Estimates using the average B contents of the rock-forming minerals gives bulk $\mathrm{B}$ for the rocks in the range $2-3 \mathrm{ppm}$. This indicates that in most cases only minor alteration has occurred and the low B contents may be a good representation of typical B in granulite terranes.

The average B content of all the rocks is 12 ppm, and a weighted mean to represent the lower continental crust has been calculated as $9.3 \mathrm{ppm}$.

\section{References}

Ahmad, R. \& Wilson, C. J. L., 1981. Uranium and boron distributions related to metamorphic microstructure evidence for metamorphic fluid activity. Contrib. Mineral. Petrol. 76, 24-32.

Carpenter, B. S. \& Pilione, L. J., 1981. Lithium and ${ }^{6} \mathrm{Li}$ analysis with the nuclear track technique. Amer. Nucl. Soc. Trans. 34, 141-143.

Fleischer, R. L.; Price, R. B. \& Walker, R. M., 1975. Nuclear Tracks in Solids, p. 509-514. Univ. California Press, Berkeley.

Harder, H., 1961. Beitrag zur Geochemie des Bors-Teil III: Bor in metamorphen Gesteinen und im geochemischen Kreislauf. Nachr. Akad. Wiss. Göttingen, III, 1, 1.

Harder, J., 1974. Handbook of Geochemistry (ed. K. H. Wedepohl), Chapter 5. Springer-Verlag.

Higgins, M. D.; Truscott, M. G.; Shaw, D. M.; Bergeron, M.; Buffet, G.; Copley, J. R. D. \& Prestwich, W. V., 1984. Prompt-gamma neutron activation analysis at McMaster Nuclear Reactor. In Proc. Int. Symp. on Use and Development of Low and Medium Flux Research Reactors (eds. O. K. Harling, L. Clark Jr. and P. Von der Hardt). Suppl. to Atomkern energie Kerntechnik, vol. 44, p. 690-697. K. Thiemig, Graphische Kunstanst u. Buchdruckerei A. G., Munchen, F. D. R.
However, eliminating three strongly altered samples lowers the average to $3.3 \mathrm{ppm}$, and the weighted mean to $2.8 \mathrm{ppm}$ : the latter is our best estimate for the lower crust. However, this estimate is based on only 55 samples from 7 small areas, with broad assumptions of reasonable weighting proportions. More studies of "lower crust', rocks are under way to provide a larger data base for interpretation.

Acknowledgements. This research work was supported by NSERC grants A0155 and E6626 to D. M. Shaw. The PGNAA system is a jointly-owned facility of the McMaster Nuclear Reactor and Nuclear Activation Services Inc. The authors wish to thank J. Whorwood for photography, L. Hillier for typing.

Malinko, S. V.; Berman, J. B.; Lisitsyn, A. Y. \& Stolyarova, A. N., 1969. Boron in rock forming minerals based on data from a local radiographic analysis. Int. Geol. Rev. $21,1274-1284$.

Manning, D. A. C. \& Pichavant, M., 1983. The role of fluorine and boron in the generation of granitic melts. In Migmatites, Melting and Metamorphism (eds. M. P. Atherton and C. D. Gribble), p. 94-109, Shiva Pub. Ltd.

Pichavant, M., 1983. Melt-fluid interaction deduced from studies of silicate- $-\mathrm{B}_{2} \mathrm{O}_{3}-\mathrm{H}_{2} \mathrm{O}$ systems at 1 kbar. Bull. Mineral. 106, 201-211.

Shaw, D. M.; Cramer, J. J.; Higgins, M. D. \& Truscott, M. G., 1984. Composition of the Canadian Precambrian Shield and the continental crust of the earth. Proc. Symp. on Composition of the Lower Continental Crust. J. Geol. Soc. London (in press).

Stinson, R. H.; Egelstaff, P. A. \& Holden, R. M., 1975. A high resolution neutron camera for diffraction experiments. Can. J. Phys. 53, 52-57.

Truscott, M. G. \& Shaw, D. M., 1984. Boron in cherts and Precambrian siliceous iron formations. Geochim. Cosmochim. Acta 48, 2313-2320.

Waskowiak, R., 1969. Beitrag zur geochemie des Bors im Kristallin von Ruhla-Brotterode (Thuringer Wald). Geol. $18,432-440$. 